\title{
AECD- 4115
}

CLITON ENOTNEER NORKS

TEXIESSES EASFIMI CORPOUTr IOA

Contraet Io. 11-7401-eng-23

DEVBLOPIENT DIVISION

Dr. C. E. Larece, DLreotor

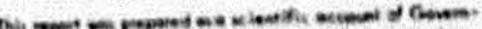

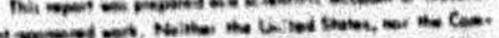

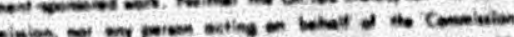

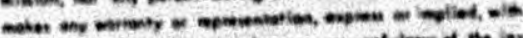

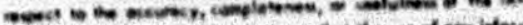

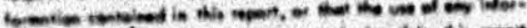

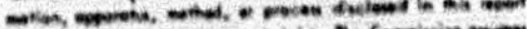

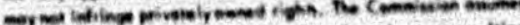

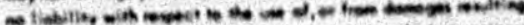

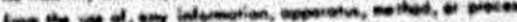

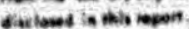

\section{THE RBACTION OF PERRIC CHLORIDS}

WITH UQANION TETRACIIORIDE

\section{ABSTRACT}

Sol1d forrio ohlor 1de resots with ool1d uranlum totraohloride to form a oomplox Iren-uranlum ohlor 1de oompound at approximatoly $263^{\circ}$. The vapor preseure of this oompound is nearor to that of uranium totraohloride than to the vapor prosesure of forrlo ohlorldo.

B. H. Baines

v. P. Calkino

Cak RLdgo, Tanneaser January 20,1947

\section{4}

Photostat Price S

Microfilm Price s

Avoilable from the

Office of Technical Services

Department of Commerce

Washington 25, D. C. 


\section{THS REACRION UP FERIC CRCOAJE}

\section{DITE DZASTUM TLTRACB.OS:DS}

\section{Ditropuction}

The oocurrence of falee $\mathrm{J}$ 's together with the frequant proseneo of apprepiable anounts of Irce In oharge materlal has led to tho Invaotgation of the poselble formation of a aompound oontalning both uranius and lran and having a vapor prossure greater than that of olthor urantun tetra-

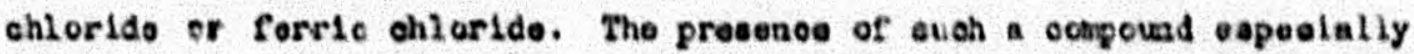
If Its Iron to uran lum ratio wore high could ocacelvably aocouat for faloa $J$ ocourrence. In oddltion, the proconoe of an 1ron-uranlum oompound with a lower vaper proseure than that of $\mathrm{PeCl}_{\mathrm{g}}$ would .100 bo of Intereat dua to the frequent purifleation of $\mathrm{VCl}_{4}$ from Iran by aublimation of the totra. ohlorido.

Since the Iron In ohargo matiorlal normally oocure as forrio ohloride thio Investigation was ooffinod to a otudy of the latoraction of the anhydrous forme of solld forrlo ohlor1de and solld urasiun totrachloride.

\section{EXPERTENTAL}

Inttial experiments eoneloted of observing viouelly the results obtainod by gontly hoating a nixture of $\mathrm{PaCl}_{3}$ anc $\mathrm{OCl}_{4}$ undor $\mathrm{H}_{2}$ in a pyrex tube by meane of a buneen burcer. When a certaln polnt to tha hesting operation was reached the greanieh olack nlxture chengod abruptly to a buff-oolored naterial, Indlceting that one type of chemieal reaction:

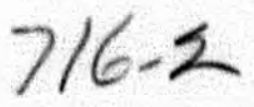


had enaued. Hoe furthe hesting, the buff-ool ored meterlel deoomosod, furaing a greon molt end volatile $\mathrm{PaCl}_{3}$ which oondmaed in the eooler perticna of the tube.

A nlxture of $\mathrm{VCI}_{4}$ and $\mathrm{PaCl}_{3}$ oorreaponding to a molar ratio of I to to wa placed la a pyrox tubo ond hented undor vacuun in an olectric furnece, the temperature betag aeneursd by use of a chromel alumal thernooxple and a Brown recorling potentleater. A platoau in the heatlng ourve wase obteined at $263^{\circ} \mathrm{C}$, and $\mathrm{an}$ oool thg the buff-ool ored o ompound wae found to heve formed. In a soond run in which the heating was stoppod at a tean purature slightly lose than $263^{\circ} \mathrm{C}$. the buff anterial had not been formed, thus establiahlag the fast that the oscurronce of the plateau was conourreat with the formation of the buff-colored compound.

Daing the roocrding potentlomoter, mixturos of $\mathrm{OCl}_{4}$ and $\mathrm{PaCl}_{3}$ varying in initlal aolar retio of Po/U from approximately $1 / 6$ to $5 / 4$ wero heated and the teapernture at which the oompound formed was found to be easentlaliy conetant at $265^{\circ} \mathrm{C}$, regardlesa of the laltiel ratlo of $\mathrm{Fo} / \mathrm{U}$. Som of thlo buff-colorot ocapound was proparod under vecuum using axcoss $\mathrm{PaCl}_{3}$ and after formation was hold betwoen 260 and $285^{\circ} \mathrm{C}$. for three hours

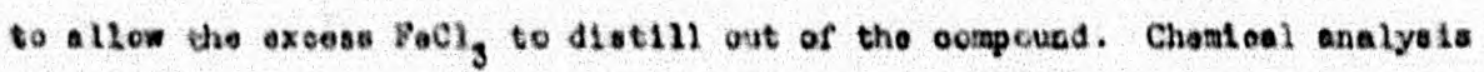
of tilis metorial gave us the enperical formula $\mathrm{V}_{7} \mathrm{FoCl}_{28}$. A vapor prosouro rus by the transpiration method was nade nt $440^{\circ} \mathrm{C}$. on some of the oompound propared in this nannor and It was foued that deccmposition tokes place at this terngerature.

Another porticn of the compound, propared as etated above, wao placed In a porcelati bcat Inside aqurte tube ard nested under $\mathrm{S}_{2}$ gas 


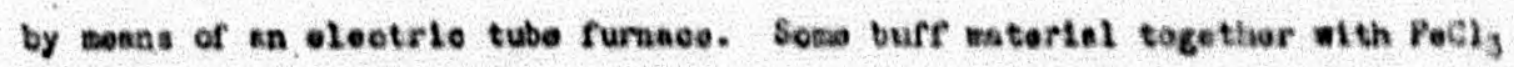
distillad at epproximately $320^{\circ} \mathrm{C}$, oolloeting ch the walle of the eovlar por. tion of the tube. The PeCl 3 becemo predominant and some of the materini in the bont hed turned dark greor at $350^{\circ} \mathrm{C}$. Indleating that some desompoeition was taking place. Evidenes of doecopesitlen inareased with terporature and - green melt was formod at $650^{\circ} \mathrm{C}$. whloh eontalned only $0.5 \%$ Po by ehontonl analys ts and had a $\mathrm{CL} / \mathrm{V}$ ratlo of 4.5 .

Another portian of the oompound, propared in the wannar previously doesibed, was heated in a pyrox tube undar vacuun by weans of en oloctria Nurnaev. The buef anterlal began to d1etlll by $400^{\circ} \mathrm{C}$. and eviden oe of den

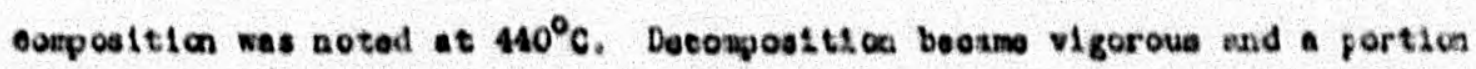
of the materlal explodod at $550^{\circ} \mathrm{C}$. On rurthor hoating vigorous decorposition oould be eoen and by $675^{\circ}$ all of tho aterlals had volatilisad. Durleg thlo run the material in the hot soav remelned buff-eolored Indioating that both docomposition produots volatilisod ae noon as formad.

\section{CONCLOSIONS}

Yrom these exporimente it is ovident that a onground of U, Fo and Cl wae formed whon $\mathrm{OCl}_{4}$ and $\mathrm{FoCl}_{\mathrm{g}}$ wero heated togother. The conpcund formed at $263^{\circ} \mathrm{C}$. and had a vapor prosaure betwoen thet of $\mathrm{PoCl}_{3}$ and $\mathrm{CCl}_{4}$. It dooomposed beforo lto molting polnt was resohod and decoapositicn becane quite vlolont at approximately $650^{\circ} \mathrm{C}$. In vacuun. Docospoaltion ylolds $\mathrm{UCl}_{4}$ and a volatilo $Y_{0}$ compound (proaumably Pocl 3 ).

Since the compound la not formed untII $203^{\circ} \mathrm{C}$. and has no appreolablo vapor prossure unt1l a tomperature of 320 to seg? io resohed, it cen not 


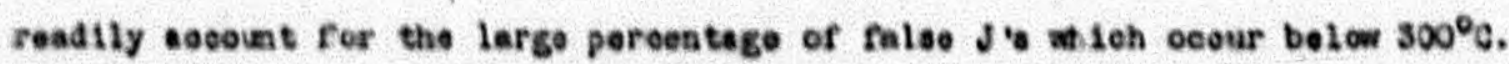
Th1s eoupled with the faot that 11ttle eorreletion has beon found botween the Iron ogntent of eherge materiel and false $\mathrm{J}$ ocourronee vould seen to indigato that this oospound oould not aseount for any eppreolable pareentage of the ralao J6.

Purifieation of $\mathrm{VCl}_{4}$ from PeCl 3 by oublimation would obviousily be conplioated by the formation of this compound during sublination olnce this froa-uraniun compound has a vapor proseure much nearer to that of $\mathrm{VCl}_{4}$ than

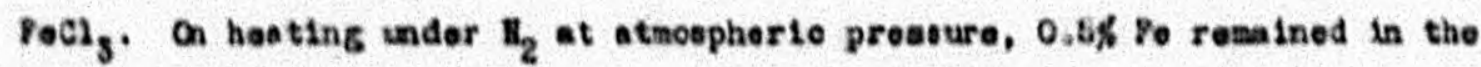
molt formod at $550^{\circ} \mathrm{C}$. Ch hoating in vacuo the oompound did not deoompose uat1l a tomperature wao roaohed ouch that both deoomposition produeto (UCl, and PoCly) volatilieed almoot Immodiatoly.

Pomperatures where the vepor pressure of the acmpound becomes appreclablo or where deoozposition takes place readily are near the tomparature whore $\mathrm{NCl}_{4}$ aublimos. Forrito chlorldo has a vapor pressure of $35.5 \mathrm{~mm}$. at $256^{\circ} \mathrm{C}$., so that removal of the $\mathrm{PoCl}_{3}$ by holding the temperature slightly below $265^{\circ}$ for some time would be preforred rather than allowing the compound to form and then attempting to desompose it or sublime it away from the $0 x_{4}$. 

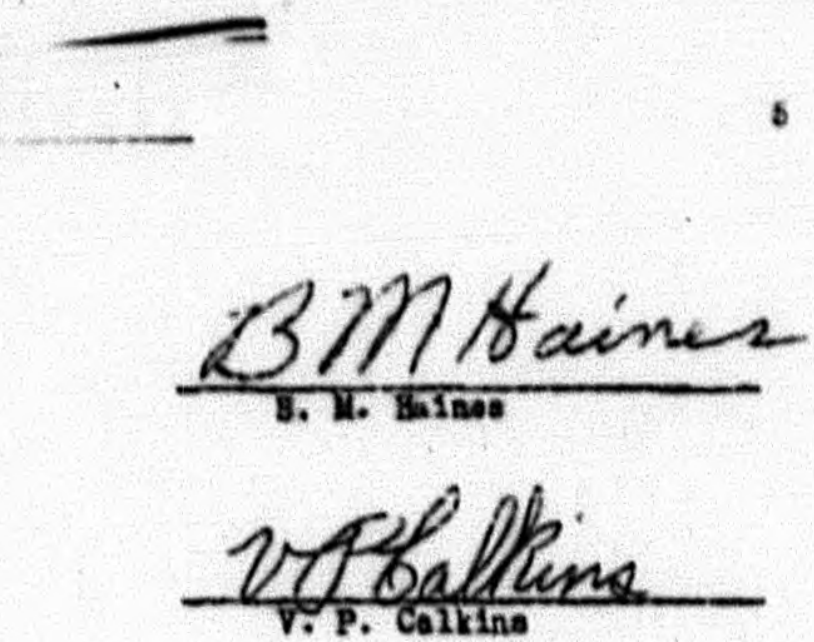

BNE/ap

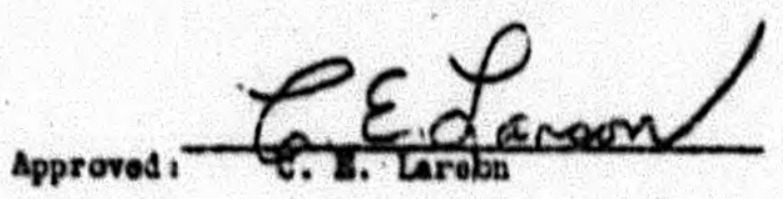

Dato Subenittedı January 20, 1947

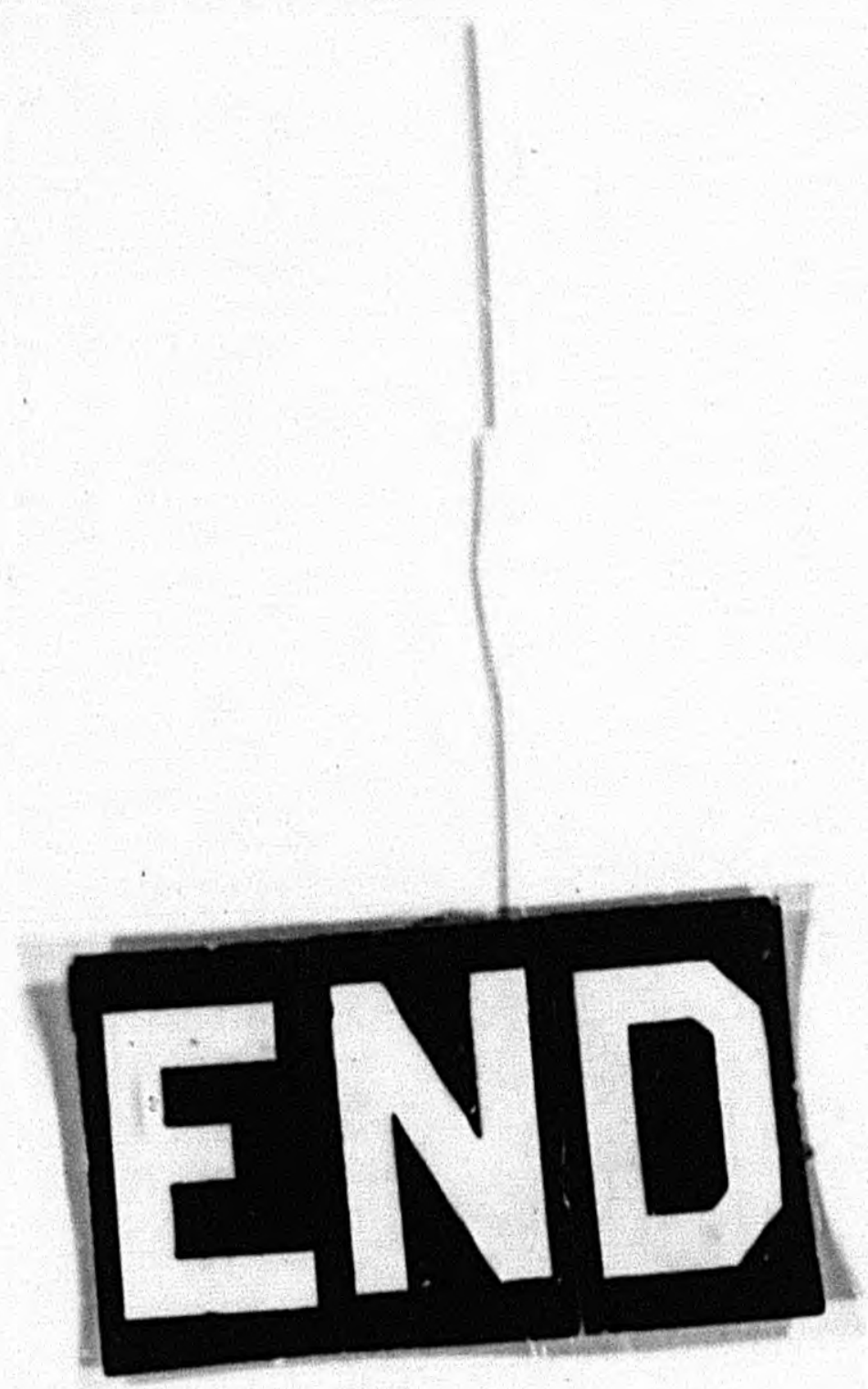

$716 \cdot 6$ 